\title{
TEACHERS' QUESTIONING STRATEGIES IN ACHIEVING STUDENTS' SPEAKING COMPETENCE IN ENGLISH CLASSROOM
}

\author{
Moh. Yasid \\ Universitas Negeri Surabaya \\ Moh.17070835037@mhs.unesa.ac.id \\ Ahmad Munir \\ Universitas Negeri Surabaya \\ ahmadmunir@unesa.ac.id \\ Pratiwi Retnaningdiyah \\ Universitas Negeri Surabaya \\ pratiwiretnaningdiyah@unesa.ac.id
}

\begin{abstract}
The study investigates the grilling system teachers applied at school to know the learners' answers and 'the" teachers' reasons for achieving students' speaking competence in English classrooms. The qualitative method is chosen to see the researcher's question responses, the observation in the classroom, and some questions toward the educators. As the findings implied, the two teachers required prompting, changing cognitive demand levels, and providing additional information in display type more dominant than others questions strategies and effective communication. The teacher at the private school repeated the questions and translated them into Indonesia or mixed the questions to relieve the learners' understanding about inquiries and responses effectively. Nevertheless, the totality of English was engaged by the teacher at the state school. The students were easier to understand simpler after the teacher explores many questions and applied much longer time toward the wait time method. The study presented the helpful results of the questions used when the teachers operated in the teaching and learning process and upgraded learners' responses in participating in the learning process. This study offered effective teachers' questioning strategies in increasing learners' communicative skills, particularly in achieving speaking competence.
\end{abstract}

Keywords: Questioning Strategies, Speaking Skills, and Teachers' Questions, Classroom Activity

\section{A. INTRODUCTION}

\section{$\mathrm{I}$}

$\mathrm{t}$ is an essential part of the English as a Foreign Language learning process in the classroom teaching. The educator possesses several essential targets in delivering the knowledge toward the learners, such as the learners are able to speak English well with others. There are several cases students face when they have great will to communicate in the English language. Finally, they cannot reach their goals because of several factors till they feel bored in the classroom. "The interface of educator in increasing students' capability must be a very crucial factor" (Alanazi \& Widin, 2018:34). Moreover, the English teacher has a critical factor in reviving the lazy students in the classroom to be more active. The educator has to be 
more creative to create provocative questions for students so that they participate with other students, such as the teacher should not apply complex questions such as (why and how) before applying informative questions such as (what, when, where, who).

Classroom interaction process determines the language learning successful; it is caused by the engagement of the teachers and the learners in the classroom interaction. Some understandings of language classroom talk have experienced in many sectors. Nunan (1993) observed that the classroom speech that happened in the class is a distinctive type. It explains that the oral practice of language becomes a matter of discourse in the classroom language. The same point with it, Allahyar and Nazari (2012:12) quarreled that "applied beneficial questions will more endorse the process of learning and communication in the class." Therefore, to maintain the learning process, the teacher needs to be creative by creating several importand methods to make the students active in responding to the questions.

The teacher has an essential role and determines the students' high participation in teaching effectively to understand the materials easily. Interactive teaching methods make the learners feel more enjoy the classroom activity instead of the uninteractive class (Hand and Keles, 2012). The teachers in the classroom interactions create the communication core so that the learning role is more significant. The educators can apply questions methods to accomplish answers from the students (Yang, 2017). It means that in pursuing good learning and teaching, the teacher should be more creative. Nowadays, the methods of the questions that some teachers apply are not appropriate and not effective. When the teachers ask the questions without knowing the answers, it will get several problems in regular teachings. Finally, the authority of classroom teaching will be affected.

The teacher must need speaking competence when giving the question strategies to make the learners more enthusiastic. Bailey (2000) declared that to achieve the learners speaking skill the teachers should possess the good competence in speaking skill. In creating a communicative learning process to develop the teaching and learning activity, the educator needs speaking skills. Besides, the teacher's method in applying the questions must use an effective and attractive approach to make it easier to communicate and interact.

Furthermore, in the Nigerian study, many schools' location becomes a significant factor that can affect the students' achievement proven by some studies in getting the intellectual competence. On the contrary, Zappala (2002) and Macmillan's (2012) findings stated that the locations of the places in not important to be a factor and there is no reason to affect the learner's outcome and competence in village or city school that is given the same experiment. 
Several studies explained the teaching and learning process in applying to question of the classroom context. Etemadzadeh, Seifi, and Roohbakhsh (2013), Yesil and Korkmaz (2010), Albergaria-almeida (2010), Ocbian and Pura (2015), Isfara and Fitriati (2017), Rido (2017), Keles and Hand (2012), Affandi (2015), Nizma (2017) squabbled evidently about the technique of effective questions tobe scheme in generating the learners' participation and writing.

Additionally, research accomplished by Affandi (2015) concerning "display and referential questions" employed in delivering speaking skills illustrated that a lot of teachers applying "display questions" more than referential questions. For illustration, teachers employed "display questions" in demonstrating speaking. Nevertheless, the referential questions are expected to be applied to promote a real contact and display open discussion in the teaching space (Affandi, 2015). Comparably, Nizma's study (2017) discovered that the educators exercised more "display questions" than "referential questions" since the learners possess a standard capacity in communication expertise established on their empirical of the subject. Furthermore, since the content of the subject that was given to the learners in inviting participation, the teacher employed many "display questions". In addition, established on two preceding findings, it can be seen there are considerably dissimilarity consequences. Besides, Nizma's study (2017) disclosed that teachers in private school incline to employe display questions. On the other hand, Affandi's study (2015) established that teachers in state school applied more in "referential questions" in practicing English.

Refers to previous research on how to ask teachers to the students about materials provided and how the teachers at different schools applied different techniques. So, this study is going to assess the strategies of questioning in achieving students' speaking competence in English classroom. Additionally, the difference in questioning strategies are used by English teachers in achieving students speaking skills will be overviewed.

In sequence to solve the reseacher's novelty apportioning with educator's inquiring and explaining approach in explaining English to persuade learners' classroom interface, so that, the study aims to explore the approaches are applied by teachers to accomplish discourse skill for tenth students, to distinguish the learners' reactions concerning teachers' approaches applied in classroom, to distinguish the aim why the appraoches applied are not same. 


\section{B. REVIEW OF LITERATURE}

Questions are the most corporate design of classroom activity. The teacher initiates the answers, one of the student's answers, the teacher gives feedback, initiates the next question, and so on (Sinclair \& Couthard, 1975). Some considerations should be used by the teacher when providing the question. It is a universally used activation technique in the process of learning and teaching. Moreover, the teacher must have reasons why he or she asks the question to the students and have knowledge about the criteria and strategies for questioning.

Appropriate to the important of questioning as a teaching method, questioning strategies that used by the teacher are received as a consideration amount of attention in a teacher education. Accoding to Wigle (1999) a strategy that used to ask the questions had better reach the next purposes: enthusiastically comprise all learners in the process of learning; create an struggle to arrange a response in fostering all learners; permit sufficient wait-time for processing of cognitive; and engage the higher-level thinking to ease opportunities for learners. However, Lewis (2007) asserts that question performs a core role in the instruction development, teachers require to plan the question carefully. Futher, he argues that when a teacher employs questions effectively, students will discover that question is very beneficial learning tool. According to Xuerong (2012) and Walsh (2011), questioning strategies are classified into two categories: the strategy of question-planning and questioncontrolling. The strategy of question-planning has a purpose to classify problems to produce response, better comprehend learners' understanding, and encourage for further discussions. Moreover, "question-controlling strategies are procedures used by teachers to ask questions in the classrooms in order to distribute turn-taking and encourage participation" (Rido, 2017:27).

In the classroom communication, there is a substantial amount of inquiring performances for facilitating students to react the questions of teachers and provoke their thoughtful skill. For instance, Cole \& Chan (1987) recommend five questioning techniques: pausing, changing level of cognitive demand or question switching, rephrasing, providing additional information and prompting. Meanwhile Ellis (1994), Richard (1990), and Thomas (1987) propose five techniques of questioning, namely, rephrasing, repetition, simplification, probing, and decomposition. Similar to Wu (1993), she described that the teachers exploited five questioning schemes when no reply was"approaching. They were: rephrasing, simplification, repetition, decomposition (breaking down an initial question into several parts, and probing). 
In delivering the questions toward the students, the teachers also need good speaking skill. "Speaking is a productive language skill" (Siahaan, 2008:95). It means that speaking is a skill of someone that is understood by other speakers in producing sounds that exists at the meaning of someone's talks, so that a good communication is created by them. Brown (2001) stated that someone can carry on a moderate conversation expertly when he can speak a language. Rehearsal opportunities, tasks and various elements of language activation." "Those are provoke the students to gain smoothly phrases and words employing without a lot of intentionally thought" (Harmer, Jeremy: 2017, 123). The teacher provides stimuli and sufficient time in making the students talk a lot is as first criteria of a good teaching speaking activity is. Thus, the teacher is not the only dominant here. Besides, a minority talkative participants do not dominate then opportunity to express and increase contributions and equalised are independently allocated in each talk of classroom is as the second criteria.

Moreover, as the third statement of successful speaking activity that should be emphasized by the teacher: highly motivated of the students. They are so excited to express and concerned in, because of the interesting material or topic, or likly they need to provide to accomplish an objective of assignment or because they are concerned in technique that teacher uses.

Furthermore, a successful speaking activity uttered in a Course in Language Teaching is as the fourth criteria: language is of an acceptable level. It means, when the students are stating in appropriate language and undoubtedly to understandable each other, they comprehend each speech. Hence, it is able to imply that they speak throughout adequate level of language accuracy (Ur, 1996). Furthermore, the questioning strategies delivered by the teachers should be ralated toward the classroom discourses. In the classroom discourse, it explores teaching exercises and practices among students and teachers (Hasan, 2013). In classroom language learning based, the interaction can be stimulated from many accomplishments, for instances group discussion, pair work and also by giving questions.

\section{METHODOLOGY}

This study used qualitative study to prepare effective and reasonable description of the teachers' approachs of questioning applied by english teachers. The design of qualitative research accomplished to create the results be displayed descriptively to get a clear description of teachers' questioning strategy to be analyzed in accordance with the original data in a systematic and factual. The method of qualitative employed to catch in complexity assessment 
dispensing with the matter (Creswell, 2012) which in this circumstance teachers' questuoning approach.

The study participants were two english teachers which each of them is from different school (state and private school) and different university graduation were included in this study. The researcher examined the approachs of squestioning employed by the educators in explaining the learners in practicing the various strategies, different background and different experiences in teaching based on several considerations why the subjects were chosen.

In this study, the data were represented starting audio records of two teachers. The data were included uttered reports obtained from the teachers practices in the classroom intearction. For about 60 minutes the lesson ran. Two approaches were exercised to gather the data. The first is from the classroom. Audio-records were applied in getting the teachers' questioning approaches and learners' uttered reports in the classroom observations. The sheets of examination were also exploited to note down every behavior that applied by the teachers' and learners' during the class regarding the questioning approach of teachers and students' uttered reports. The second is from interviews. Interviews were done with two English teachers. It amed to discover or investigate their views to the questioning appraoch of teachers to employ the learners' uttered reports. Both english teachers were interviwed before and after the classroom observation held.

Then, the data were alanyzed by four steps. According to Miles, Huberman, and Saldana (2014), there are four steps in analyzing the data, they are data condensastion, data coding, and conclusion drawing. The first, all activities in the classron were observed and recorded by the the researcher. Then, the recorded utterances data were transcribed into the written forms. After that, enumerate the questionings approach established on teachers communicated to the learners afterward, categorized and normalized the data by utilizing coding. Then, the reseracher analyzed the data about the questions given and how the learners answered to the explanations to exemplify the questioning methods employed in the classroom by the teachers. In conclusion, analyzed the data to know the questions applied in maintaining the classroom communication.

\section{RESULTS AND DISCUSSION}

This results display three questioning methods that mostly applied by english teachers in this study offered by Cole \& Chan (1987). They are prompting, rephrasing, and providing additional information. Prompting strategy is a strategy utilized in implementing communication interventions with others directly. The strategy of promptings are able to 
respond quickly done by the students. As stated by Mousavi (2018) in learning english is effective when applying questioning startegy both in long or short terms. So, it shows that the startegy of prompting is very good tobe applied in teaching and learning process to invite the learners activeness.

Teacher A:

T : "How do you know the letters types?" (meeting 1:13)

Ss : "Two, dua Mom!"

S2: "There are two, Mom!"

The example above, the prompting strategy applied by the teacher to ask the question with dispaly question. The materials were asked by the teacher whether they knew or not about it by applying the strategy of prompting question. The prompting method were in the bold forms of teacher's utterances. This strategy is effective for the students in responding the question faster.

$\mathrm{T}$ : "For the first, in writing letter, what should we do?)

Ss : "Date sir...!"

S4 : "We should write the date!"

For this example, in getting the the responses from the students, the examiners applied the questions of display. The educator applied the questionings of prompting method to obtain the learners' idea greater meanwhile applied in other questions too. In the same way, to call the learners' involvement in performing the feedback, the teacher applied the strategy of prompting questions.

Moreover, Rephrasing became the second questioning strategies mostly used by both of English teachers at schools. In other way, to ensure that the learners comprehend or not, this strategy must be applied.

The next questioning strategy is changing the level of cognitive demand employed by the private school teacher. For example:

T: "What do you know about the letter of electronic, Husna?"

S9: “..........” (silence).

T: "Husna, what is your belief concerning an electronic letter?"

S9: "It is online letter."

The case in this example, for the first, the question was given by the teacher, unfortunately the learners did not find yet the question performed purpose. It made the learners did not understand so that they can not give a response. To ease the students easy to 
understand the questions, the teacher should change it by switching the questions given in order that they gave a response to the question.

In a different way, providing additional information strategy applied by the teacher. As an example:

T: "........as we learned, can you mention the types of the letter, ?"

S5: "yes sir, formal, informal and semi-formal letter" (Meeting 1: 48-49)

The additional information was given by the teacher in this meeting to explain the students before answer the question. It will make the learners understood because the teacher gave the information at the first time. Besides, this strategy helped the teacher to invite the learners' interaction the classroom.

The startegy of pausing is also applied by the teacher to ease the student in understanding the materials. Below is the example:

T: "How do you know the systematic of the leatter?"

Ss: "emmmm.........." (no answer)

S1: "Two sir, three sir"

After analyzing the example above, it can be said that the students' understanding will be known when applying pausing strategy. In this case, the display type questions was used by the teacher.

Rephrasing is the last strategy that applied by the teacher to increase the learners' comprehending when they confused to the questions given by the teachers. In the rephrasing strategy, the teacher replaced the type of question grade to maka the students easier in giving the responses to the questions.

T: "Akbar, what is your opinion?"

S8: "Sorry sir, what does it mean?"

T: "Which ones do you like, do you like an online letter?"

S8: "Of course sir., I like better online".

For this case, applying rephrasing strategy is effective to help the students in understanding the purpose of the questions given by the english teacher. Meanwhile to see the students' ability toward the material given, the teacher applied a display question in giving the question. Thus, in order that the learners comprehended and responded easily toward the question given, the rephrasing strategy is applied by the teacher in learning process.

Established on the results and investigation concerning the students' responses at different schools in the classroom, the teachers are able to ilustrate numerous changes results in applying the methods. The state students have changes results balanced with the students 
of a private students in responding to the methods of questions applied by the teachers. Moreover, it happened at each meeting that it is caused by several factors, such as classroom conditions, the kinds of questioning strategies, and question types.

The students of state school have different methods in responding the teacher's question types applied in the classroom interaction. For instance, the students gave various responses when the teacher applied any staretegy of questions. The students tended to respond to the questions based on what they know from thier knowledge.

$$
\text { S2: “...Due' mom!” (meet 1:14) }
$$

From the example, the learners answered what they know becasue they have limited knowledge or they still don't understand toward the questions. Comparably, the students will give different responses although the questions strategy was same but the questions type is different.

In addition, the other questions strategy that also important is changing the level. Usually, the proffesional teacher also practiced this strategy to help the students difficulties when givin the types of question. To ease the students in understanding the questions, the changing level strategy is needed to applied by the teacher to give explaination toward the questions before.

T: "What is the feature of E-Mail, do you know it?"

$$
\text { Sss:"“......."(Silence).(3:98) }
$$

In this example, when the students were silence, the teacher must change the level of the question in order that the students easy to respond, because in the example above the learners did not understand. So, the different strategy should be given in this case.

The next strategies of questions that applied by the teacher is providing additional information. The teacher practiced providing additiona information strategy to help the learners in responding the question when they found the difficulties about the materials.

S5:"Yes me sir, informal,semi-formal and formal" (Meet 1:49)

It can be explained, before asking the question to the learners, it is better for the teacher to give the additional informations first then giving the question. So, the responses that given by the student will be better when the display question given by the teacher.

The last is rephrasing strategy. This strategy helped the students in understading the meaning of the questions because they can answer the questions easier.

T:"What is your opinion Akbar?".

S8:"Sir, what does it mean”.(meet 2: 86-87) 
In this example the students asked the teacher about the purpose the meaning of the question maybe because the students stil did not understand the content of the questions given.

Based on the analysis results toward the students' respones at state and private school above can be concluded there are several differences results from the strategies used by the teachers. The students of state school has different results compared wtih the students of private school in responding the questioning strategies applied by the. Moreover, it happened at each meeting that it is caused by several factors, such as classroom condition, the kinds of questioning strategies and questions types.

The students' responses of state school were engaged on discovering the most effective strategy that used by the teacher in seeing the students' reactions in employing the strategy of questions. Moreover, the students also give good resposes after given rephrasing strategy based on the findings while providing additional information make the students of state school comprehended the teachers' questions. Based on the data collected analysis throughout students' responses, several of students of state school were found really helped after the teacher gave rephrasing strategy and providing additional information toward the misunderstanding the questions and finding the correct responses. It is different condition of students of private school that were more passive in the classroom. In concerns to the learners' responses concerning the employment of questioning strategies, the students gave better responses after given questioning strategies in comprehending the teacher's questions. The students of private school were easier to understand when the teacher gave display questions than referential questions. More than it, the students were helped in obtaining their conviction to express their ideas verbally by employing since several questions strategies, such as prompting, providing additional information, rephrasing, and pausing. Thoses strategies are able to construct the confidence of students in providing the responses. Furthermore, the students' responses toward the teachers' questions used more short answers in the teaching and learning process.

From the results above, the teachers applied five different strategy of questions, some common responses which occurred in the classroom interaction were regularly used display questions type because the teachers both at state and private schools used more display questions than referential questions. So, the students responded more by using display questions to answer the questions. Moreover, when the teacher applied several important questions for the students, they can give more answers and longer responses. It means that 
the students were more active in participating and answering the teachers' questions in the classroom activities. They were helped and understand the questions given by the teacher that used different questioning strategies. So, the questioning strategies used by the teacher had improved the students speaking competence.

For the teachers' reasons, to improve the interaction of the students in the classroom, the teacher should applied specific issues. The teacher practiced numerous kinds of questions to promote the praticipation of the students in the classroom, the questions "how, what, why" as types of referential questions. One of the teachers methods to promote the students' participation is applying display and referential questions in helping the students in responding their questions. So, the learners participated actively and responded the questions well after the teachers applied this question strategies.

Additionally, sometimes the same questions were repeated by the teacher when giving the questions for the students to see the understanding of the students related toward the questions given before. When the learners did not understand still, so the teacher repeatde and change the level of question tobe easier. Example below is as the reasons:

I:"When the student cannot answer the questions, what do you do?"

T: "Repeat the questions by applying simple of questions, when the students still do not understand, I change the level questions".

(teacher of state school: 23-24)

For this case, when the student cannot answer the question, the teacher change the level question tobe more simple so that the student understand. But sometimes the students still did not catch the purpose of the questions, in this case the teacher sometimes must translate the questions into indonesia in order that the student can find the asnwer.

However, the teacher at private school had different view related to the results obtained when applying the strategies of questions in practicing toward the learners. In his statement, when the teacher applied interesting and fun method in teaching, the learners were more active to participate in the classroom interaction. In addition, when the teacher applied the referential and complex questions, the learners were active to participate asking and responding the questions in the classroom teaching. To motivate the learners' participation in exploring their idea, the teacher applied a display and a referential question.

Furthermore, the same questions usually needed tobe repeated by the teacher also to see the students' responses. Besides, it was done to see whether they understood or not related to the materials. In motivating the learners of private school, the teacher had various strategies to keep the participation in the classroom. For example, the teacher asked the simple and easy 
materials to invite the learners' interaction, then the teacher gave higher level of questions. The condition of learners in responding the questions is different. The strategies of questions is applied by the teachers to help the learners in learning english and to teach the learners easier in accepting the materials. When the teachers applied difficults strategy in giving the material, the students will find many difficulties. In addition, the teacher in applying the strategies of questions should see the students' condition first, because the level of students' knowledge is also different. So, the teacher should give the good strategies in order that the learners understand the questions given.

The questions strategies applied have advantegs and disadvantages related with the teachers' application. The results of applying questioning strategies was eliciting the learners' in participating the classroom interactions because the students were more active and they responded the questions more convinced. In actual fact, the learners got many improvement after the teachers applying the strategies they practiced in the classroom related to the materials given. In addition, the learners' eager and motivation were improved compared before giving the questions strategies. The strategies gave time to provide the students to respond the questions better because they had the reasons to give answer when the students found difficulties and did not understand toward the questions. So, they still had a time to prepare it by applying various and good strategies.

Meanwhile in formulating the questions to be more creative that can be applied in the classroom became the problems for the teachers. The teacher applied the questioning stratgies as creative as possible in teaching the students. As stated by Rismayanti (2018) that a response that is followed by person to whom engaged is a part of the uttered expression question. Moreover, it is also correlated to the questions types that are employed by the teachers as the reasons and significances in inviting the students' participation. In addition, to apply the strategies of questions in the classroom acitivity, the teachers should provides numerous substantial approaches. It is very important to see the learners' level of language mastery in giving the questions strategies. Thus, the teachers are supposed to understand well the their students' character and knowledge level in order that the teacher can give appropriate questions strategies to the learners based on the learners' language mastery. Timing became significance strategy in giving question. The time allocated in the class activity is extremely incomplete, hence the teacher needs to consider applying it astutely so that the other accomplishments that had been designed can be accomplished efficiently in the classroom. 


\section{E. CONCLUSION}

This study found that questioning strategies skill would give important impact in enhancing the responses of learners' verbal communication in the learning process. The use of questioning strategies in the classroom can organize the lectures, lead the learners concerning a individual reaction and encourage interfaces. It can be revealed that the questioning strategies application give chances for the learners to communicate the ideas. In fact, in teaching english subject particularly speaking competences, both teachers that taught at different school were competent and talented. They practiced several endeavour and applied strategies of question in improving their skill.

The teachers should plan their questions to ensure that they match the teachers' pedagogical goals. They should also ask questions which require students to engage in various kinds of verbal responses which help promote students' learning. Next, as not all students are able to respond to all questions, teachers should nominate volunteers because this gives opportunity for other students to respond to teachers' questions. Teachers should also help students formulate questions and make time for students' questions as this facilitates learning and demonstrates a higher level of engagement.

In short, the researcher illustrated that in inviting several questions, teacher regularly applied inviting for interpretation or confirmation in asking the responses. When the students didn't catch the teachers explaination, they usually employed asking for evaluation that were using when students occasionally practice English and the teachers corrected the students' pronountiation, whether it was good or not in EFL.

\section{REFERENCES}

Affandi, Y. (2015). Teacher's Display and Referential Questions in Teaching Speaking. State University of Surabaya Press.

Alanazi, M. J. M., \& Widin, J. (2018). Exploring the Role of Teacher Talk in Saudi EFL Classroom: Importance of F-Move in developing Students' Spoken Skill. Arab World English Journal (AWEJ), 9(1), 307-320.

Albergaria-almeida, P. (2010). Classroom Questioning: Teachers' Perceptions and Practices. Procedia - Social and Behavioral Sciences, 2(3), 305-309. https://doi.org/10.1016/j.sbspro.2010.03.015

Bailey, K. M. (2000). Issues in teaching speaking skills to adult ESOL learners. NJ: Lawrence Erlbaum Associates, 1(2), 113-164.

Cole, P. G., \& Chan, K. S. (1987). Teaching Principles and Practice. Prentice Hall.

Considine, G., \& Zappala, G. (2002). The influence of social Economic disadvantage in the academic performance of school students in Australia. Journal of Sociology, 3(8), 127-148. 
Creswell, J. W. (2012). Educational research: Planning, conducting, and evaluating quantitative and qualitative research. In Educational Research (Vol. 4). https://doi.org/10.1017/CBO9781107415324.004

Etemadzadeh, A., Seifi, S., \& Roohbakhsh, H. (2013). The role of questioning technique in developing thinking skills : The ongoing effect on writing skill. Procedia-Social and Behavioral Sciences, 70(1), 1024-1031. https://doi.org/10.1016/j.sbspro.2013.01.154

Isfara, G., \& Fitriati, S. W. (2017). Teachers' Questioning Strategies to Elicit Students' Verbal Responses in EFL Classes at a Secondary School. Journal of English Education, 5(2), 217226.

Keles, N., \& Hand, B. (2012). The Questioning Strategies Affecting Teachers' Implementation Levels of the Argument-Based Inquiry. International Periodical for Language, Literature and History, 12(17), 227-244.

Macmillan, M. J. (2012). School location versus academic Achievement in Physics: Does Computer-Assisted Instruction (CAI) Has Any Effect? Journal of Educational and Social Research, 2(8), 65-73.

Miles, M. B., Huberman, A., \& Saldana, M. (2014). Qualitative Data Analysis (Third ed.). Sage Publication, Inc.

Mousavi, K. (2018). Input Providing vs . Output-Prompting Negotiation Strategies in Learning Grammar among Young EFL Learners. International Journal of Instruction, 11(2), 497-512.

Nazari, A., \& Allahyar, N. (2012). Increasing Willingness to Communicate among English as a Foreing Language (EFL) Students: Effective teaching strategies. Investigation in University Teaching and Learning, 1(1), 18-29.

Nizma, A. A. (2017). The Use of Display and Referential Questions in Teaching Learning Process in MTs School. State University of Surabaya.

Nunan, D. (1993). Introducing discourse analysis. London: Penguin English

Ocbian, M. M., \& Pura, J. E. (2015). Questioning Strategies of Literature Teachers among Grade 8 Filipino Students. Asia Pacific Journal of Multidisciplinary Research, 3(4), 42-51.

Rismayanti. (2018). An Analysis Of Teacher's Questioning Strategies During The Classroom Interaction At Piba Of Uin Alauddin Makassar. Uin Alauddin Makassar.

Yang, H. (2017). A Research on the Effective Questioning Strategies in Class. Science Journal of Education, 5(4), 158-163. https://doi.org/10.11648/j.sjedu.20170504.16

Yesil, R., \& Korkmaz, Ö. (2010). A comparison of different teaching applications based on questioning in terms of their effects upon pre-service teachers ' good questioning skills. Procedia - Social and Behavioral Sciences, 2(3), 1075-1082. https://doi.org/10.1016/j.sbspro.2010.03.151 